\title{
Conflict management in the Caucasus via development of regional identity
}

\author{
Olga Vassilieva
}

\section{Introduction}

$\mathrm{T}$ HIS CHAPTER CONSIDERS the preconditions for and possibilities of Caucasian integration as a way of conflict management in the region. The 1990s has revealed that a common Caucasian identity might be used for "constructing' a regional security community. To testify to this thesis, a significant part of the chapter addresses the question of how different identities have influenced the development of nationalism and cooperation, conflict escalation and conflict settlement since 1990. It analyses the impact of different cooperative organisations on conflict management, both directly and via the changes in governmental policies towards ethnic conflict and the identities which fostered it. Of special interest are the current policies of the 'external' powers (Russia, Turkey, Iran and western countries) and the possible changes in their policies towards the region, which might promote the construction of a regional security community and, as a consequence, conflict management in the Caucasus.

A high conflict potential in the Caucasian region, and in the North Caucasus specifically, is conditioned by 'natural' causes of conflict such as a poly-ethnic and poly-cultural population, the scarcity of resources (primarily territory), a high population growth rate, extensive migrations and, at the same time, the preservation of compact ethnic communities. Soviet national policy based on the idea of ethno-federalism smoothed ethnic tensions and provided inter-ethnic peace during the industrialisation period, but it also created the conditions that promoted ethnic competition in poly-ethnic autonomous and 'union' republics since the 1960s. Among these conditions were the recognition of an ethnic identity as a national one (i.e. ethnic nationalism versus civic nationalism), the promotion of the ethnic cadre and 'intelligentsia', and the creation of a hierarchy of quasi-sovereign national-territorial units. ${ }^{1}$

Social mobilisation during Gorbachev's perestroika turned into ethnonational movements under slogans calling for the restoration (or the creation) of 
national autonomy for the 'historical territory of a particular ethnic group' that, in turn, fuelled inter-ethnic conflicts all over the Caucasus as several ethnic groups considered the same territory to be their 'ethnic motherland'.

However, together with the development of competitive ethno-national movements, different coalitions of these movements have also been created in the Caucasus: (1) at the republic level, for the purposes of settling inter-ethnic conflicts (the Congress of Dagestani Peoples) and/or to coordinate the activity of the opposition to communist leaderships in the North Caucasian republics; (2) at the regional (North Caucasian) level, to resolve common problems (the Confederation of Mountain Peoples of the Caucasus - CMPC); (3) although the idea of the Common Caucasian Home had never been realised in practice, it has been discussed: cooperative organisations had contributed to conflict resolution in the Caucasus.

Both processes - the growth of competitive ethno-national movements and the development of different cooperative organisations - reflect a multi-level choice of identity among the population of this region, who ascribe themselves to a local community, to a tribe, to an ethnos, and to particular religious or political movements. But what unites all these peoples now living in different states, is the common Caucasian identity based not on a common language but on shared myths, traditions and values.

Ethnic identity has played a key role in the development of ethnonationalisms and as a consequence, in conflict escalation, in considering the scarce resources and mutual claims. Caucasian identity resulted in the development of cooperative movements, which contribute to conflict resolution, although their influence on conflict development was much weaker than was the contribution of ethnic identity to conflict escalation.

In explaining the formation of ethno-nationalism, scholars have proposed two basic approaches - 'primordialistic', which explains ethno-nationalism via the universal and natural character of ethnicity (i.e. 'loyalty to one's own ethnic group, culture or place of origin'); and 'constructed', which considers ethnic culture and nation to be primarily social constructs, subjects for manipulation by elites in their competition for wealth and power. These were named 'imagined communities' by Benedict Anderson (Bogdanor 1987: 210).

In reality, however, it is impossible to find a scholar of nationalism who subscribes to 'primordialistic ideas'. Even Anthony Smith, who stressed that premodern ethnicity is the root for modern nationalism, did not claim the 'naturalness' of an ethno-nation, as Craig Calhoun notes in his comprehensive review of modern approaches to ethno-nationalism; the 'primordialist' approach is, in many respects, political myth and belief (Calhoun 1993).

A reasonable question arises from this conclusion: if politicians are so successful in 'constructing' ethno-nationalism, what should be done in order to construct successful regional cooperation or a security community in the 
Caucasus? Who are the political entrepreneurs interested in such a social construct?

Karl Deutsch defined a 'security community' as an integrated group, where:

By integration we mean the attainment, within territory, of a 'sense of community' and of institutions and practices strong enough and widespread enough to assure, for a 'long' time, dependable expectation of 'peaceful change' among its population. By Sense of Community we mean a belief on the part of individuals in a group that have come to agreement on at least this one point: that common social problems must and can be resolved by processes of 'peaceful change', By peaceful change we mean the resolution of social problems, normally by institutionalised procedures, without resort to large-scale physical force. (Deutsch et al. 1957: 5)

The Caucasus has demonstrated a strong sense of community and a Caucasian identity, which has deep cultural and historical roots. The development of cooperative organisations in the region show the possibility of establishing 'institutional procedures' for the peaceful resolution of social problems. Strong ethno-nationalism resulted in a short life for integrative associations.

What is presented here is an idealistic attempt to implement "pure theoretical conclusions' from studies of [ethno-]nationalism to conflict management in the Caucasus, i.e. it is an attempt to suggest possible strategies for the construction of a security community in the Caucasus, using its 'primordialistic' allCaucasian identity, the construction of which may become the basis for peace making and peace building efforts in the region.

For these purposes, how different identities have influenced the development of nationalism and cooperation, conflict escalation and conflict settlement in the Caucasus within the last decade have all been considered. The impact of different cooperative movements on conflict management directly, and via the changes in governmental policies towards ethnic conflict and the identities which fostered it, have also been analysed. Of special interest are 'the external' powers (Russia, Turkey, Iran and western countries), their current policy (or how it is perceived among Caucasian people) and possible changes in their policies towards the region, which might promote integrated communities and, as a consequence, conflict management in the Caucasus.

\section{A multiple choice of identities and their impact on conflict development}

A multiple choice of identity defines the different means of consolidation and mobilisation during the second wave of nationalism in the Caucasus. ${ }^{2}$

\section{'Natural' sources for ethnic identity and 'Soviet constructivism'}

An ethnic identity, which differentiates between 'them' and 'us' on the basis of criteria such as common cultural traits, common history, language and attachment 
to a certain territory has provided a high degree of group solidarity in the Caucasus. In many situations, it has overlapped identities on the lower level, such as loyalty to a local community (on the level of small villages) or ethnic subunits (teips (clans), tribes and so on). It has also destroyed common territorial identities (at a republican or regional level), and political identities ('pro-democratic' movements), which revealed themselves in the Caucasus in the 1990s.

The fast and mass ethno-national consolidation during perestroika resulted from the presence in the Caucasus of both important factors in ethnonationalism: the strong loyalty of the population to a particular ethnic group and a class of political entrepreneurs ('national intelligentsia', 'national cadre', 'national bureaucrats').

In comparison with other national regions of the former Soviet Union, the special importance of ethnic loyalties has been conditioned by the traditionalism of Caucasian societies which, in turn, can be explained by several factors. Throughout the centuries, the topography of the Caucasus has fostered the high level of diversity among local communities and the preservation of their compact settlements and their traditional economic and social life. Owing to a geographic position on the crossroads of major routes between Europe and Asia, the Caucasus became a battlefield for great empires and has been exposed to invasions by nomadic tribes. The wars and invasions prevented attempts at selforganisation and the formation of modern states and resulted in a 'primitive' economic life and the conservation of traditional political institutions for many years.

Russian colonisation and the modernisation of the Caucasus did not significantly change the traditional structures of society, especially in the North Caucasus, which resisted Russian invasion until the beginning of the twentieth century. Local communities considered loyalty to traditional institutions and the traditional way of life a resistance to Russia's colonial policy.

Soviet national policy also failed to significantly modernise traditional life and ties. Moreover, its essence was based on the recognition of national identity as an ethnic identity. 'The support of and development of national cultures' in the form of creating national theatres, film production, national academies of science and humanities, etc. helped not only to create a whole system for the reproduction of ethnic myths, but also to promote the preservation of ethnic identities. For many small ethnic groups, this policy resulted in the creation of the 'political entrepreneurs' of ethno-national movements during perestroika, and the 'national intelligentsia' and 'national cadre'.

Policies of assimilation and resettlement (other elements of 'social constructivism') often had the same effect: they provoked the resistance and, in many cases, promoted the re-establishment of traditional institutions. Svetlana Alieva, a daughter of a well-known Karachaev writer who had survived during the years of deportation (1943-57), notes that it was during the deportation 
that 'stareishiny' (the older Karachaev men) prohibited marriages between Karachaevs and non-Karachaevs, which had been widespread during the 1920s and 1930s.

Urbanisation and economic modernisation could have influenced the transformation of traditional ties in a society. However, the Soviet policy of levelling the standards of economic development was carried out by means of intensified industrialisation; it did not affect the traditionally agricultural occupations of the local population and required the regular import of qualified manpower from other regions of the Soviet Union. As a result the local population worked in agriculture and was employed in the upper echelon of power, while immigrants, who were concentrated in the cities, were employed in industrial production and the medium echelon of administration.

The specific system of employment fostered the conservation of traditional ties, structures and, as a consequence, ethnic identities. The Soviet policy of recruiting national cadre was based on the class principle (representatives from among the peasants, agricultural workers and industrial workers were preferred for the administrative services) and on the national 'representative-ness' principle (all different national groups had to be represented in power bodies). Having got a position in the Soviet administrative system, new bureaucrats strove to help people from their local communities to get a position in administrative hierarchy. In the poly-ethnic autonomous regions of the Caucasus, such an approach exacerbated inter-ethnic competition and provided a large number of collective grievances. The different statuses in the Soviet hierarchy (being a union and an autonomous republics, or an autonomous oblast and okrug) defined different access to resources, and also promoted competition among ethnic elites and the conservation of ethnic identities.

Thus, the Soviet national policy directed at creating a new social construct, 'Homo Soveticus', in reality fostered the development of both the essential elements for ethno-national mobilisation: the preservation of traditional ethnic identities and the creation of ethnic entrepreneurs, which included national bureaucrats, national intelligentsia and national managers of small and medium-sized enterprises (SMEs). ${ }^{3}$ All these groups considered perestroika a chance to significantly change the ethnic balance in administrative structures in favour of their ethnic groups and to get access to additional resources. The weakening of the central authorities and the elimination of the Communist Party of the Soviet Union, which broke the ethnic balance in administrative structures, accelerated ethnic mobilisation, especially in the regions where strong ethnic grievances had persisted - such as regions with resettled ethnic groups (oppressed peoples, many peoples of Dagestan, etc.); regions with a territorial hierarchy of ethnic units (Georgia, Azerbaijan); or with an administrative hierarchy for ethnic groups (especially, in dual-ethnos autonomous regions such as Kabardino-Balkaria and Karachaevo-Cherkesia). 
The development of ethno-national movements pushed the countermobilisation of neighbouring ethnic groups and strengthened tensions between local communities. The ethnic mobilisation and countermobilisation, as well as the competitive purposes of ethno-national movements resulted in a wave of violent interethnic conflicts all over the Caucasus.

\section{Cooperative associations at the republican level, or 'democratic constructivism'}

Cooperative organisations in the North Caucasian republics were conditioned not only, and not so much, by the traditional common Caucasian identity, but also by the common political 'pro-democratic' or 'self-determination' stance of the leaders of national organisations. Certainly, the adherence of leaders of the so-called 'informal movement' to democratic values was much weaker than their strong ethnic loyalty. However, the joint struggle against the Communist Party leaderships in the republics explains the cooperation among new political elites, which resulted in the settling of several inter-ethnic conflicts.

The cooperation was conditioned by the history of the 'informal movement', which had developed at the end of the 1980s around ideas of democratisation and human rights. Most upcoming organisations tried to unite activists irrespective of their nationalities. National parties were closely connected with 'pure political' (democratic) organisations and were often headed by the same leaders. Their programmes declared citizenship for all those living on the territory of would-be republics. Inclusive nationalism at this stage was caused by a number of factors. In some regions, the informal movement, including national parties, stemmed from the dissident movement of the 1970s which was based on the idea of individual human rights rather than group rights. In other cases, the leaders of ethno-national movements strove to get support for their nationalist slogans from other ethnic groups, living on the same territory. Sometimes, the devotion to a local community (an incompleteness in ethno-genesis) influenced the delay in ethno-national mobilisation.

Certainly, associations and joint ethno-national organisations with opposing and competitive aims were weak and were doomed to a rapid disintegration. However, from time to time, the confrontation between old 'communist' elites, which had stayed in power, and new 'democratic' parties promoted cooperation between competing ethno-national organisations. These attempts included the creation of electoral clubs to support non-communist candidates in the parliamentary elections of 1989 and 1990; the formation of small democratic factions in the republican Supreme Soviets in 1990; and the coalition of democratic and national organisations under the slogans of 'democratisation' and the reelection of the Communist republican leadership, which supported the coup in August 1991. None of the coalitions of the ethno-national organisations and movements in the republics, except Dagestan, declared conflict settlement to be 
among their goals. However, they created the environment, a workshop for 'interactive problem-solving', which fostered negotiations and personal contact among leaders of competing ethno-national organisations that, in turn, positively influenced conflict resolution (see Chapter 6 in this volume). The role of the 'third party' was usually played by leaders of other ethnic associations. ${ }^{4}$

The associations of new political parties of different ethnic groups had an additional impact on conflict settlement. Fears that the opposition could unite on the democratic platform and challenge the former communist elites stimulated official leaders to search for a compromise on such issues as the ethnic 'representative-ness' of power structures and control over resources. The proposal of the Congress of Peoples of Dagestan to elect parliament according to ethnic quotas and to provide for the rotation of power structures was reflected in the 1994 Constitution of Dagestan and its electoral law. The parity of ethnic groups in the power structures of Adygeya, Karachaevo-Cherkesia and Kabardino-Balkaria became a compromise among acting officials. ${ }^{5}$

Sociological surveys showed that a significant part of the population in the North Caucasian republics supported such an approach. During an all-North Caucasian survey in 1996, 54.4 per cent of the surveyed people in Adygeya were satisfied with how their ethnic groups were represented in the legislative branch of power and 53.6 per cent evaluated the 'representative-ness' of executive power positively. In Dagestan, it was 37.9 and 35 per cent, respectively, in Ingushetia 63 and 59.8 per cent, in Kabardino-Balkaria 55.2 and 50.8 per cent, in Karachaevo-Cherkesia 50.0 and 43.8 per cent, and in North-Ossetia 55.2 and 53.2 per cent. ${ }^{6}$ The balance in the political 'representative-ness' of ethnic groups and some degree of public consensus testified to the realisation of some forms of consociational democracy in the republics. ${ }^{7}$

The consensus among ethnic elites resulted in attempts to redefine the notion of nationhood; although an ethnic approach still dominated, it is possible to find signs of a transfer to a civic, inclusive nationalism in the North Caucasian republics. Both notions of a 'Dagestani people' and 'Dagestani peoples' are present in the Constitution of Dagestan. 'The people of Kabardino-Balkaria' are mentioned along with the 'Kabardin people' and the 'Balkar people' in the Constitution of Kabardino-Balkaria. Although a mixture of approaches has dominated in political discourse, transition away from an ethnic notion of nationalism is important for conflict transformation and the construction of regional identities.

\section{The 'Common Caucasian Home'}

The idea of the 'Common Caucasian Home' is the essence of a common Caucasian identity. This identity is also based on common values, beliefs and traditions. Moreover, these traditions formed around the idea of conflict resolution 
and mediation. An ethnic and religious mosaic, the scarcity of resources as well as the preservation of primitive forms of political and economic life, especially in the mountains of the Caucasus, often led to conflict. These conflicts could last a very long time, considering the Caucasian terrain, the use of primitive weapons and the roughly equal balance of capabilities, which did not allow one party to win overall and establish a new political regime. In these conditions, the peoples of the Caucasus elaborated rules to mediate conflicts via meetings of the elders from warring tribes, the invitation of third-party mediators, people's diplomacy and many other elements of pre-modern conflict resolution techniques. To prevent conflict, many traditions were established like, for example, sending children to grow up in a neighbouring tribe, hospitality for travellers, protection even for enemies if they came to the house, blood revenge, and others.

During the 1990s, there were several attempts to create regional organisations, with the final goal of creating a 'Common Caucasian Home'. All these organisations have defined the boundaries of this house differently, some of them considered it to be only the North Caucasus; others included Transcaucasian states. The reasons for this stemmed from recent Caucasian conflicts and reflected alliances which developed over centuries or under the pressure of current political conditions. ${ }^{8}$

\section{The North Caucasian level: traditionalism as a regional ideology}

There were several attempts to create cooperative movements at the level of new political leaders as well as among the official elites of the North Caucasian republics and administrative regions of Russia. Among them only the Confederation of Mountain Peoples of the Caucasus (CMPC) created in the summer of 1989, and the North Caucasian Economic Association of Local Councils and Executive Bodies of the Regions of the North Caucasus (the Economic Association) founded in the summer of 1991, have worked for a relatively long time and influenced conflict resolution in the region.

The main objective of the CMPC, incorporating sixteen national movements, was defined as the coordination of activities for solving the problems of 'small' Caucasian peoples, namely, (1) inter-ethnic conflicts (providing conditions for negotiations between the confronting sides), (2) political lobbing (for solving the problems of the oppressed peoples, enhancing the prestige of national movements at the regional and federal levels, etc.) and (3) assisting the cultural integration of the North Caucasian peoples.

The sphere of CMPC activity was limited from the very beginning. First, the competition among ethno-national movements at a republican level influenced the activities of competing ethnic movements in the CMPC: if Adygean (Kabardin, Cherkess, Adygean, Abazin) and Ossetian national movements defined the CMPC's actions, Karachaev, Balkar and Ingush leaders participated 
in the CMPC round tables only from time to time. Another reason for the unequal participation was central federal policy, specifically the Federal Rehabilitation Law, which was approved in 1991 and guaranteed territorial rehabilitation. The national movements of the oppressed peoples considered the federal centre the main and most powerful ally in achieving their purposes. The federal centre, in turn, made every effort to destroy the CMPC, which expressed support for Chechnya's demand for independence.

Secondly, the covert struggle of the different blocs for the leadership of the CMPC (e.g. between Adygeans and Vainakhians, Chechens and Ingush), the contradictory objectives of national movements and the personal ambitions of leaders had circumscribed the range of the CMPC's major programme guidelines. The CMPC as well as the other cooperative associations was in fact used by its members to defend the interests of their ethnic groups: e.g. Ingush hoped to use the CMPC to make Ossetians recognise their rights to territorial rehabilitation; Ossetians, in turn, strived to repel Ingush territorial claims. Chechens, who were interested in support for their national aspirations, considered the CMPC a 'first step' to independence for the Caucasus.

Thirdly, the consolidation of the CMPC became possible due to external factors: Georgian policy towards South Ossetia and Abkhazia as well as Russian policy towards Chechnya. This factor defined the geographic boundaries of cooperation. For example, the CMPC did not accept the membership of Svan and Megrel organisations (western Georgian subethnic groups) which, in turn, influenced the transition of Abkhazian-Georgian tensions to military actions in 1992-93.

Despite all the internal controversies, the CMPC provided the mechanism for negotiations in ethnic conflicts in all North Caucasian republics. The inability of the CMPC to settle the Ossetian-Ingush conflict was conditioned by the fact that this military conflict developed as a conflict between the Ingush national movement and the official leadership of North-Ossetia, which had had no personal contact or groundsfor negotiations. The Ossetian national movement failed to halt the development of the conflict, as (1) it was involved mainly in the long-running Ossetian-Georgian conflict and (2) it maintained an unofficial status that prevented it from having any influence on the North-Ossetian authority. Besides which, after the approval of the Rehabilitation Law, Ingush leaders preferred to appeal to Moscow directly, and did not participate in regional organisations.

The CMPC was successful in initiating the negotiations between the national movements of mountain peoples and the Cossack Hosts in the South of Russia (they are dispersed through Rostov, Stavropol and Krasnodar territorial units, as well as in national republics of the North Caucasus). 'Round tables' managed tensions between Cossacks and 'Caucasians' in the Caucasus in 1993-94.

The idea of the Caucasus as a Common Home for Cossacks and mountain peoples provided the basis for their cooperation. Traditionalism (using the tradi- 
tional methods of conflict resolution among peoples in the Caucasus and fostering the ideas of common history and roots) became a peculiar analogue of nationalism at the regional level, and it possessed the main features of nationalism, i.e. heedfulness of a common past, hopes for the future, and a specific role for the poly-ethnic Caucasus as a bridge between two civilizations - Muslim and the Christian, between the West and the East.

Despite the popularity of the idea, the common Congress of the Peoples of the North Caucasus had been postponed several times. Pressure from the Russian federal centre, which feared the strengthening of separatist tendencies in the Caucasus, was one of main influencing factors. Traditionalism and the appeal to the past also resulted in the failure of the initiative: the shadows of the Caucasian War against Russia in the nineteenth century to a great extent contributed to the failure of this initiative. The decrease in popular support for the political movements led to a situation where the initiative naturally expired.

The contradictions and competition among national movements speeded the decline of the CMPC. Besides, the CMPC failed to elaborate common constructive approaches to the Caucasian Federation. The idea of Caucasian unity outside the Russian Federation, which was proposed by the Chechen leadership, exacerbated the internal tensions in the CMPC; although many peoples criticised Russian policy towards the Caucasus and the military intervention in Chechnya, few in the North Caucasus supported the idea of independence from Russia. However, the declarations to build a united Caucasus outside Russia resulted in a situation whereby the Russian leadership began to consider any cooperative movements created without its sanction as a threat to Russian interests in the Caucasus and undertook actions to destroy such cooperative movements. The transformation of the population's political activity to the economic sphere also influenced the decline of the CMPC during 1995-96.

The federal centre itself tried to use the idea of a common Caucasian identity and initiated several cooperative organisations. The North Caucasian Democratic Congress, the Assembly of the Peoples of the Caucasus, several round tables of representatives of ethno-national parties were held under the aegis of the Nationality Soviet of the Russian Supreme Soviet (1993) and the Ministry for National Affairs and Regional Policy between 1993 and 1995. However, these attempts enjoyed little, if any, support in the region, and their impact on conflict resolution was insignificant. They incorporated small and unknown organisations, the leaders of which hoped to increase their status at local and regional levels through their participation and federal financial support. An uncohesive and unclear Russian policy towards the Caucasus forced national movements to keep away from the Federal centre, which had enjoyed their support in 1989-91.

The North Caucasian Economic Association of the Local Councils and Executive Bodies of the Caucasian Regions reflected, primarily, the idea of the 
geographic and economic unity of the region. The Association did not consider conflict settlement a central objective of its activities. Members of the Association have adhered to the principle of non-intervention in 'internal' affairs and the refusal of mutual territorial claims. ${ }^{9}$ However, the Association contributed to conflict settlement in the Caucasus where many ethnic groups were divided by administrative boundaries. Joint economic activities and project development might create an economic basis for the development of a supra-ethnic, Caucasian unity.

\section{The Caucasian community}

One more level of Caucasian cooperation is the unity of the Caucasus on both sides of the Caucasian range. In recent years, this idea has developed from pure declarations of the Common Caucasian Home breaking away from Russia (the role of the new integrating centre in such a 'home' was assigned to either Tbilisi or Grozny) to an elaborated concept considering cooperative institutions and regional ideology.

Alexander Kukhianidze, a Georgian political scientist, proposed, for example, the model of 'Caucasio-central' democracy (Kukhianidze 1995). In his opinion, inter-Caucasian relationships should be based on the ideology of centrism, counting on 'reaching mutually acceptable decisions'. This principle could become 'the Caucasian reply to the globalisation and separatism that destroy a national state from the top and from the bottom'; it would reflect 'modern tendencies in state inter-connections: the formation of regional democratic communities'. The structure of this cooperation should include an all-Caucasian two-chamber Parliament, in which one chamber would incorporate national authorities (three Caucasian states and Russia); the other would join representatives from autonomous republics, regions of South Russia and national minorities. In Kukhianidze's opinion, the right to veto for both chambers would have to guarantee the balance of national and local interests. It might resolve tensions between authorities of Transcaucasian states and Russia, on the one hand, and state, local authorities and national minorities, on the other. The model should also include some executive bodies as well as regional peacekeeping forces created 'not on the basis of nationality', that could be used only in the case of ethnic conflicts or natural disasters.

Obviously, however, the realisation of this model would face significant problems, which were not considered in the scheme. For example, it would be difficult to elaborate norms for representation: should Russian or Armenian minorities in every subject of the Caucasus be represented in the Parliament? Also, who can be considered national minorities? The combination of representatives from state-like autonomous republics and a part of the population (national minorities) would inevitably produce tensions. Beginning the discussion of such issues, however, would promote the development of this initiative. 
In 1998, several attempts to organise the Meetings of the Heads of the Caucasian States, Republics and Regions were undertaken. However, this cooperative initiative was short-lived. Several factors influenced the inability to move towards stable regional cooperation. Modern Caucasian conflicts weakened the cooperative potential. The participation of external actors (Russia, Turkey, the international community) and their competition for influence in the region exacerbated tensions among Caucasian states and peoples. The contradiction of international approaches to state sovereignty (self-determination versus the inviolability of state boundaries) also influenced centrifugal tendencies in the Caucasus. Joint economic projects, which could promote peace in the future, have resulted in competition for foreign investment and for the pipeline itinerary from the Caspian Sea. Besides, fearing the recognition of sovereign status for their autonomous republics, the Transcaucasian states are not ready to participate equally with representatives of minorities and local republics authorities.

\section{The current situation in the Caucasus}

Excluding Chechnya, the current situation in the Caucasus can be best described by the formula 'no peace, no war.' The unstable balance might be easily broken.

\section{Internal conditions}

At present, most conflicts in the Caucasus are frozen. The implementation of specific forms of consociational democracy could settle ethnic tensions in autonomous republics of the North Caucasus. Ethnic cleansing along with the separation of conflicting groups by a third-party intervention stopped conflicts in North-Ossetia, Georgia and Azerbaijan, although inter-ethnic peace there might turn into a new conflict at any time.

In the North Caucasus, both the major tendencies of a return to the confrontation between the ethno-national movements and the transition to more stable forms of consociational democracy, may come about with almost equal probability. The realisation of one of them will depend on the combination of many factors: the ability of the federal centre and local authorities to overcome socioeconomic crisis; the development of cooperative institutions and rules accepted by all of the major political actors; the openness of the decision making process, especially in conflict regions; and the transfer of significant power to the local level.

The East Caucasian region has the most unfavourable economic, social and demographic conditions in comparison with other parts of the Caucasus. The Ossetian-Ingush conflict led to the ethnic cleansing of the Ingush population from North-Ossetia, but Ingush hope to return to their houses in the future. The federal centre might solve this problem by buying the properties, but owing to the 
corruption at different levels, the population itself has not received a significant part of any aid. In Dagestan, consensus among major ethnic groups on power distribution and ethnic quotas in the government and parliament was confirmed in the 1994 Constitution. The Russian wars against Chechnya (1994-96 and 1998 onwards), although preventing the development of other conflicts, have also threatened the stability of the region in the long run.

Although socio-economic conditions in the West Caucasus are more favourable, preconditions for new ethnic mobilisation are also preserved in KabardinoBalkaria and Karachaevo-Cherkesia. These republics failed to elaborate their own models of ethnic representation in power structures, and disputes among ethnic elites arise from time to time. These disputes can lead to the mass mobilisation of ethnic groups, as happened, for example, in Karachaevo-Cherkesia after the 1997 presidential elections, when a Karachaev representative won. After numerous Abazin and Cherkess protest meetings, the federal authority annulled the results of the elections. In Adygeya, the political dominance of the titular ethnic group guaranteed by the Constitution has led to tensions between Adygeans and Russians, which numerically dominate the republic.

In the Transcaucasian states, the 'freezing' of some conflicts resulted from the fact that the central governments of Georgia and Azerbaijan de facto lost control over republics. This situation can easily turn into inter-ethnic conflict again. For example, the central government and political forces in Georgia are not ready to recognise the federal structure of the Georgian state (this provoked conflicts in the 1990s); in turn, the Abkhazian and South-Ossetian governments have insisted on independent status, after the 'victory' and expulsion of the Georgian population. The fragile balance might be easily broken if the central governments try to restore control by using military forces.

\section{External powers}

The activities of external powers have also helped preserved the 'no peace, no war' situation. First of all, however, it is very difficult in some cases to define 'external factors'. Whether Russia, for example, should be considered an external or internal factor in the Caucasus, remains a question. Politically and geographically the North Caucasus is a part of the Russian Federation. Should the participation of North Caucasians in Abkhasian-Georgian and GeorgianOssetian conflicts be considered part of Russian official Caucasian policy? In turn, how should the leaders of the Transcaucasian states involved in direct negotiations with political elites of North Caucasian republics of Russia be considered? How should the participation in conflicts of officers of the former Soviet (now Russian) army who have stayed in the Caucasus, and whom the local authorities have continued to consider a reliable help in all situations, be considered? Could this explain the involvement of Russian military forces in 
inter-ethnic conflict and political struggle in the Transcaucasus (e.g. Georgia in 1992)?

Frozen conflicts in the Caucasus, in many respects, result from the uncertainty of a transitional phase. The relationships among neighbouring countries and peoples, which became 'foreign' in 1991, are, in many respects, defined by common historical experiences, common values, ethnic ties between peoples of the North Caucasus and the Transcaucasus (Abkhazs and Adygeans, Ossetians, Avars, Lezgins, etc.), and even personal contacts among the members of the Communist Party Central Committee Politburo (Boris Yeltsin, Eduard Shevardnadze and Heydar Aliev).

Meanwhile, the disintegration of the Soviet Union, led to the involvement of other countries in the region after two centuries of the Russian domination, mainly neighbouring Turkey and Iran, which had actively participated in Caucasian politics for centuries. The ethnic proximity of Turks and Turkic language-speaking Caucasian peoples makes other ethnic groups fear Turkey's involvement in regional affairs. Russia, where about twenty Turkic languagespeaking peoples live, is apt to see Turkey's turn to the North as malice prepense.

Western countries that had abstained from active involvement in the region's affairs for a long time began to show some interest in the region - from the supervision of peacekeeping operations (currently fulfilled by Russian military forces under the supervision of the United Nations in Abkhazia and of the OSCE in Karabakh) to the oil potential of the region. ${ }^{10}$

Only the West has not got a negative image among peoples in the Caucasus because of its traditional remoteness. It could have promoted peace in the region. However, the West does not seem to be ready to invest resources in peace making and peace building processes in the Caucasus. Criticising Russian unilateral involvement, the West carefully avoids getting involved in operations, as in the Balkans.

Considering the existing contradictions between the right to self-determination and inviolability of borders, the West would be in a difficult position to try and define its policy towards the Caucasus. All parties in Caucasian conflicts have different expectations from external interventions: some talk about the right to self-determination, others about the inviolability of borders. Georgian and Azeri governments are seeking external support to restore control over rebellious autonomous regions. Karabakh and Abkhazia, in turn, hope for recognition of their independent status, having insisted that 'the legacy of newly independent states like all over the world are based only on the empire past' (Katz 1996: 29). ${ }^{11}$ Until now, judging by events in Somalia or Rwanda, the West, and the international community as a whole, has no solution for weak or failed states if these states are not in the zone of someone's strategic interests.

External powers have essentially influenced conflict development (in both escalation and management) not only, and not so much, by their direct policies 
towards the Caucasus, but also, and mainly, owing to the expectations of Caucasian peoples. Caucasians have traditionally considered themselves as living at the crossroads of civilisations and, thus, are the focus of attention for the rest of the world; this myth has fostered both ethno-nationalism and regionalism. The image of traditional competition between Russia, Turkey and Iran overcomes its real potential. Political elites in the Transcaucasian states are apt to see discrepancies of interests in terms of the continuation of the Cold War between Russia and 'the West' and try to use 'domino-logic' in their foreign policy decisions. Perceptions of external powers have influenced the political behaviour of Caucasian elites, sometimes more than real policies and actions.

\section{A pluralistic security community in the Caucasus}

A few will argue that peace in the Caucasus can be achieved only by the participation of Caucasians in peace building. Initiating peacekeeping and peace making operations, external forces are able to stop a violent conflict but not to resolve it. External interventions might even aggravate conflict in the future because they often support mutual suspicions that the external forces are bias in favour of the opposite side.

Attempts to resolve any particular conflict in the Caucasus will have limited success. Owing to the ethnic proximity of many ethnic groups, often living in separated territories, the Caucasus demands an all-in-one treatment rather than a single operation in a particular zone. The Caucasus really needs to be integrated into a pluralistic security community (Deutsch et al. 1957). Although in many respects the decade of development of modern cooperative organisations was an unsuccessful experience, it showed that regional integration is not as utopian as it first seemed.

On the basis of an in-depth analysis of ten historical cases, both successful and failed security communities, Karl Deutsch defined two conditions essential for the development of pluralistic security communities, namely, the compatibility of major values and mutual responsiveness. Both of these conditions have existed in traditional but not political life in the Caucasus. Despite religious, ethnic, economic and political tensions, as well as numerous deadly conflicts throughout history, the Caucasus has demonstrated adherence to a common identity and common values. Sharing democratic values might strengthen the 'compatibility of common values'. Mutual responsiveness has been historically characteristic of the Caucasus, and is one of the major elements of traditional cultures. Although it would be difficult to construct them in the Caucasus, considering the socio-economic and political situation in the region, a move in this direction would have a good chance of success (Deutsch et al. 1957: 123-132).

Five other conditions, which Deutsch designated as 'helpful' for the develop- 
ment of pluralistic security communities, might be created in the Caucasus. Among these conditions are the expectation of joint economic reward, a wide range of mutual transactions, the broadening of elites, social communications links, and greater population mobility (Deutsch 1957: 133-154). ${ }^{12}$

Owing to the recent common past, 'social communications links' and the common language, which is not a necessary but is a useful precondition, are a positive legacy of the Soviet period. Some of these communications links are broken as a result of conflicts; others often become the reasons for complaints and considered 'foreign interventions'. These links have to be redefined to provide 'effective channels of communication both horizontally and vertically'. Caucasian traditions might work well in favour of such development.

The 'expectation of joint economic reward' has already demonstrated its power for conflict settlement: oil projects in Azerbaijan and oil transportation has provided real conditions for the ceasefire in Karabakh, and for improving the attitudes of Georgians to Azeris living in eastern Georgia. At the same time, projects implemented in such a way that they would benefit only several ethnic groups might foster a rise in new competitions and grievances. For example, an oil pipeline built round Armenia might cause the situation in Karabakh to deteriorate. A variant of regional economic cooperation like the North Caucasian Economic Association, but including Transcaucasian states, might become the first step to economic growth via a 'wide range of mutual transactions'.

Currently, mutual transactions in the Caucasus mainly exist only at the level of individuals involved in shuttle trading in the territory devastated by conflicts and war. Economic ties in the former Soviet Union were developed without the consideration of regional benefits, therefore the economic ties of factories in the remaining industrial complexes were orientated outside the region. The Caucasus has to develop new economic ties within the region, using a traditional division of labour. Considering the current lack of financial resources and instruments, these ties might be developed in the form of state insured barter.

Economic development and cooperation might foster 'greater population mobility'. The collapse of the economy in the region has led to a situation where many Caucasians have moved to Russia in search of jobs and education. Economic projects might create possibilities for finding work without leaving the Caucasus.

The 'broadening of elites' is another element helpful for constructing a security community. It implies two processes - the inclusion of representatives from broad range of ethnic groups into management as well as a transfer of power and responsibilities to local authorities (at the level of small districts and even villages, when considering the size of ethnic communities in the Caucasus). North Caucasian republics are making the first steps towards the realisation of consociational democracy. These attempts, along with the essential decentralisation of power, have to be continued. 


\section{Cooperation, external powers and future peace in the Caucasus}

Although the Caucasus has the preconditions and a shared regional identity for being 'successfully integrated', it seems not to have the other important element for 'constructing' regionalism and cooperation - political entrepreneurs. Obviously, only one group - current or future political elites - may be considered possible candidates. Meanwhile, the 1990 s revealed that Caucasian politicians seem not to be ready for the essential self-limitation and laborious search for compromise, without which the realisation of any model of the regional, and especially the Caucasian, community is impossible. Caucasian historians have treated the common history in different ways and promoted negative images of neighbouring peoples. The socio-economic situation in the region may be described as devastation. In such conditions, the policy of the international community towards conflict settlement in the Caucasus and Caucasian integration becomes of greater importance.

Michael Brown has given several reasons why outsider powers should care about ethnic war, even though these wars do not create direct threats to their strategic interests (Brown 1993). Ethnic war 'poses a direct challenge to important international norms of behaviour', they create 'chain reaction effects', and the problem of refugees is among them. The international community, and not only neighbouring states, might be interested in a policy promoting peace in the Caucasus. Support for integrating efforts could be one of the main applications of such policy.

Countries involved in Caucasian affairs (the West, Russia, Turkey and Iran) should coordinate their political and economic activities and avoid fostering competition among the Caucasian elites. Cooperative efforts are in need of technological and information support about experience and best practice in resolving problems and tensions as they arise. Considering the necessity of multi-level integration, the support of non-governmental sector networks might be an essential element of international assistantship.

During the past decade, the political elites in the autonomous regions of the North Caucasus began moving towards consociational forms of democracy. For many reasons, however, this tendency is weak and controversial. The governments need special expertise and help in the development of consociational democracy in developing countries. This expertise might be implemented in many other regions. The idea of all-Caucasian integration, arising difficulties and successes should be discussed widely during international conferences on regional problems. At the same time, local politicians and political scientists should get the opportunity to study world experience on relevant issues.

Obviously, however, Caucasian integration will be necessary for several decades to come or even more. But this approach to peace development in this region has no alternatives. 


\section{Conflict management in the Caucasus}

\section{NOTES}

1 There were no unique rules or criteria in the decision to confer autonomous status. Sometimes, this decision by the Central Communist Party Committee was defined by the successful or unsuccessful actions of an ethnic cadre, sometimes for other political reasons (the autonomous regions of oppressed peoples between 1943 and 1956, the change of Karelia's status, etc.). Different statuses in the hierarchy provided a different degree of control over resources (primarily, control over the regional economy) and welfare distribution.

2 The first wave was a rise in nationalism in the Caucasus at the beginning of the twentieth century.

3 SMEs were usually republican or joint republican-central property.

4 The method of the 'interactive problem-solving workshop' was introduced by Herbert Kelman (see, for example, Kelman 1991). A significant difference with the Caucasian situation is that leaders of ethno-national parties developed or used conflict resolution techniques themselves (without any training or third-party intervention), on the basis of Caucasian traditions.

5 The Congress of Peoples of Dagestan was elected by the representatives of national movements on 24 October 1992 on the basis of an ethnic quota which reflected the ethnic composition in the republic: Avars, Kumyks, Lezgins and Dargins got seven mandates, Laks and Tabasarans five, Chechens three, Tats two, and two mandates were reserved for Cossacks. The federalisation of Dagestan, which was supported by the Kumyks, Lezgins and Nogays, became the most controversial issue for this cooperative movement.

6 In Adygeya, 22.5 per cent thought that the peoples of the republic were disproportionally ('unjustly') represented in administrative bodies and 21.8 per cent said the same about representative bodies of power, in Dagestan it was 28.6 and 31 per cent, respectively, in Ingushetia 24.4 and 22.8 per cent, in Kabardino-Balkaria 20.4 and 22.9 per cent, in Karachaevo-Cherkesia 25.6 and 32.5 per cent and in North-Ossetia 21 and 21.7 per cent, respectively (Khoperskaya 1997: 221-222).

7 Lijphart introduced the notion of consociational democracy as "particularly suitable for the governance of plural societies, that is societies which are deeply divided by religious, ideological, linguistic, regional, cultural or ethnic differences'. Consociational democracy is defined in terms of two essential principles, executive power-sharing and a high degree of autonomy for the all segments, and two helpful principles, proportionality and the minority veto (Bogdanor 1991:137).

8 A variety of approaches were characteristic for the Caucasus at the beginning of the twentieth century. 'The Alliance of United Mountain Peoples of the North Caucasus'; 'the South-Eastern Alliance of the Cossack hosts, Mountain Peoples of the Caucasus and Free Steppe Peoples', 'the Transcaucasian Seim'; 'the Republic of the Union of Mountain Peoples of the Caucasus'; 'the Tersk People's Republic' and other attempts to realise the idea of a Common Caucasian Home after the February Revolution of 1917 proposed different forms of political and geographic unity for the Caucasus.

9 The official leadership of Ingushetia has recognised the moratorium on territorial rehabilitation, but has insisted on the complete fulfilment of the Law on Rehabilitation.

10 The population and political elites of the Caucasus do not distinguish between western countries because the existing policy of the West towards the Caucasus seems united in comparison with policy towards conflicts in the former Yugoslavia. Only during voting on the Karabakh problem in the OSCE in 1994 did France vote against the condemnation of Armenia. But this case has not influenced the united image of the West. 


\section{Olga Vassilieva}

11 Mark Katz has researched this problem for other cases of newly independent states (Katz 1996: 29).

12 Conditions such as 'the necessity of core areas and their capability' (Deutsch et al. 1957: 137), which was more appropriate in a 'pure realist world' before significant changes in international environment, has been omitted. Although until now foreign policy has reflected a realist approach, it is not only this approach that defines international relations. European integration testifies that the security community is possible without core areas. Two conditions here have also been conflated, namely 'superior economic growth' and the 'expectation of joint economic rewards', because, in my opinion, these are two successive stages of one process. The 'compatibility of major values' condition and the 'distinctive way of life' which Deutsch proposed to consider differently, implying again the specific Cold War situation of a different economic and political life between the East and the West, have also been joined as one condition (Deutsch et al. 1957: 134).

\section{REFERENCES}

Bogdanor, V. (1987), The Blackwell Encyclopaedia of Political Institutions (Oxford).

Bogdanor, V. (ed.) (1991), The Blackwell Encyclopaedia of Political Science (Oxford).

Brown, M. E. (1993), 'Causes and implications of ethnic conflict', in M. Brown (ed.), Ethnic Conflict and International Security (Princeton).

Calhoun, C. (1993), 'Nationalism and Ethnicity', Annual Review of Sociology, 19, 227-228.

Deutsch, K., S. Burrell, R. Kann, M. Lee, M. Lichterman, R. Lindgren, F. Loewenheim and R. Van Wagenen (1957), Political Community and the North Atlantic Area. International Organisation in the Light of Historical Experience (Princeton).

Katz, M. (1996), 'Collapsed empires', in C. A. Crocker and F. O. Hampson with P. Aall (eds), Managing Global Chaos: Sources of and Responses of International Conflict (Washington, DC).

Kelman, H. (1991), 'Interactive problem solving: the uses and limits of a therapeutic model for the resolution of international conflicts', in V. Volkan, D. Julius and J. Montville (eds), The Psychodynamics of International relationships, II (Lexington, MA), 147-152.

Khoperskaya, L.(1997), 'Developing legitimate notion of ethnos as a law subject in the North Caucasus', in l. Khoperskaya, Developing the Relationship Between the Center and Regions in Russia: From Conflict to Consensus Search (Moscow).

Kukhianidze, A. (1995), 'Caucaso-central conception of democracy', Nauchnaya mysl Kavkaza (Tblisi), 4, 66-72. 